\title{
REVIEW
}

UDC 575.113+577.217

doi: https://doi.org/10.15407/ubj90.06.005

\section{THE ROLE OF GENE GJB2 AND CONNEXIN 26 IN HEARING IMPAIRMENT}

\author{
ASMAA MISSOUM \\ Department of Biological and Environmental Sciences, Qatar University, Doha, Qatar; \\ e-mail:amissoum@live.com
}

Gap Junction Beta 2 (GJB2) gene mutations are the leading causes of hereditary hearing impairment. This gene encodes various gap junction proteins such as connexin 26 (Cx26), which facilitate $K^{+}$homeostasis inside the cochlea in the inner ear. It is as well identified in non-syndromic deafness, which is not accompanied with other abnormalities in the body and contributes to 75\% of the cases. The protein connexin 26 is composed of four transmembrane helices and two extracellular loops, in which each has three specific, highly preserved, cysteine residues held by intramolecular disulfide bridges. Moreover, 35delG and Cys169Tyr are the most common mutations of GJB2, where the former results in a shortened Cx26 protein due to the termination of coding sequence, and the latter leads to a destabilized protein structure as one of the three cysteine residuals that are affected. This short review gives further insights on how these two types of mutations lead to hearing loss.

Ke y wo rd s: Gap Junction Beta 2 (GJB2) gene, connexin 26, non-syndromic, 35delG, Cys169Tyr, hereditary deafness.

$\mathrm{D}$ eafness is a hearing impairment that can be as a result of both genetic and environmental factors, and it is estimated that approximately 1 out 1000 children in the United States only are affected by it with half of these cases are due to genetic factors [1]. Deafness comes in various levels (moderate to severe) and has different types such as syndromic (25\%), in which deafness is associated with other abnormalities in the body like blindness for example, and non-syndromic (75\%), in which deafness is not accompanied with such symptoms [2]. Most of the genetic factors that contribute to hearing loss are caused by various mutations in the gene GJB2, which is also known as Gap Junction Beta 2 and it is found in chromosome 13, and mainly expressed in inner ear and skin. This important gene encodes for many gap junction proteins such as connexin 26, connexin 30 , connexin 43 , and so on [3].

Furthermore, they are a group of membrane proteins whose main function is to facilitate the movement of certain ions, molecules, or even messengers that cannot pass through the hydrophobic part of the plasma membrane [4]. Among the various types of connexin proteins, mutations in connexin 26 (Cx26) was found to be most causing cases of deafness, especially for non-syndromic that are inherited by autosomal recessive nature, and which accounts for $70 \%$ of the cases [5]. Moreover, connexin 26 has an important function in the $\mathrm{K}^{+}$homeostasis inside the cochlea in the inner ear, and which part of the hearing process [6]. In this short review, we are going to discuss further the role of GJB2 mutations and how it leads to hearing impairment.

\section{The GJB2 gene, Cx2, and the hearing process}

The GJB2 gene was the first gene to be identified in non-syndromic hearing impairment, and this suggests its importance in the coding of connexin 26. It is the main gap junction protein in regu-

(C) 2018 Missoum A. This is an open-access article distributed under the terms of the Creative Commons Attribution License, which permits unrestricted use, distribution, and reproduction in any medium, provided the original author and source are credited. 
lating $\mathrm{K}^{+}$homeostasis during the normal function of hearing process, and which its mutations are responsible for most deafness cases [7]. Moreover, gap junction beta 2 is found in the long arms of chromosome 13 in positions 11 and 12, and has a length of 5.5 kilobases. This gene also has two exons, but only one of them, exon 2, codes for Cx26. The coding region has about 681 base pairs and the mRNA, which translates into connexin 26 protein having 226 amino acids, has a length of 2.4 kilobases [8].

When sound waves are collected by the outer ear and move through the inner canal, they hit the eardrum which has three connected bones called ossicles, and their function is to conduct vibrations to a snail shell-like structure called cochlea, found in the inner ear $[9,10]$. The organ of Corti, which found inside the cochlea, contains hair cells which sensors the vibrations accompanied by the movement a fluid called 'Endolymph' [11]. As it moves the tiny hairs back and forth causing the influx of potassium ions into them through connexin 26 gap junctions located on stereo cilia of the hair cells [11]. Afterwards, the influx of potassium ions inside the hair cells generates an electrical impulse by depolarization as illustrated in Fig. 1, which is eventually sent to the auditory nerve and thus the brain interprets as sound $[9,10]$.

\section{Connexin 26 protein}

Connexin 26 (Cx26) protein is known as a gap junction protein. It is encoded by a gene called GJB2 gene. The mutation in GJB2 gene is the most common cause of congenital sensorineural hearing loss, which accounts for $10 \%$ of all childhood hearing loss and about $20 \%$ of genetically hearing loss [12]. These percentages show the huge effect of this ge-
A

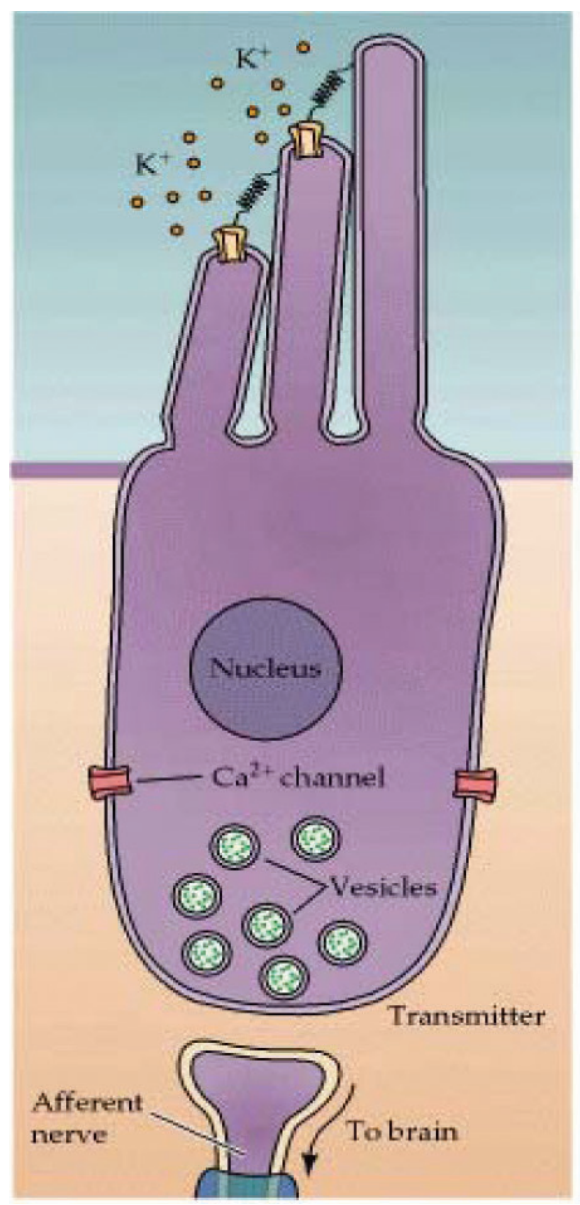

B

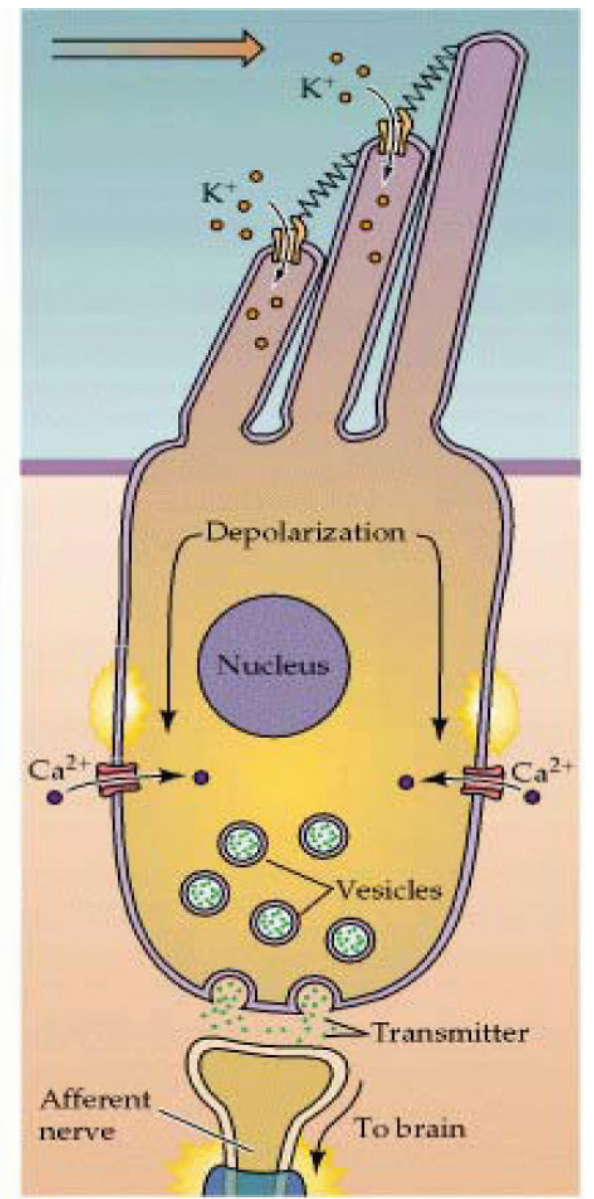

Fig. 1. A. The flow of $K^{+}$ions into the hair cells via Cx 26 gap junctions at seterosilcia tips. B. This generates deploarization, which opens $\mathrm{Ca}^{2+}$ channels. When calcium enters, neurotransmitters are realeased onto the afferent nerve [9] 
netic mutation in GJB2 gene. To find out how this mutation influences the protein structure, it is important to know its location and biological function.

Six connexin proteins are assembled together to form a connexon, which is also known as connexin hemichannel [13]. Two connexons from different cells will form a pore of a gap junction between the cytoplasm of the adjacent cells. This channel is responsible for the flow of ions and signaling molecules in a bidirectional flow [13].

Protein Cx26 is composed of four transmembrane helices (from TM1 to TM4), as well as two extracellular loops (E1 \& E2), functioning as the domains of this protein [14]. These play a huge role in the interhemichannel interactions of the connexons, where the E1 and E2 complex of one hemichannel would interact with the E1 and E2 complex of the other hemichannel, as shown in Fig. 2 [15]. There is also an intracellular loop, a cytoplasmic N-terminal helix and a cytoplasmic C-terminus [14].

The connexin protein is composed of six conserved cysteine residues that would form three intramolecular disulfide bridges between E1 and E2, which contributes to the stabilization of the extracellular region structure [15]. Each extracellular domain of the connexin protein, which are the E1 and E2 have three specific cysteine residues which are highly preserved in all connexins [16]. They form the intramolecular disulfide bridges between the cysteine residues. The disulfide bonds of the residual cysteine are between 53 and 180, 60 and 174, and also between 64 and 169 [17]. Studies on other proteins have shown that a substitution of cysteine residues would result in the destabilization of the protein

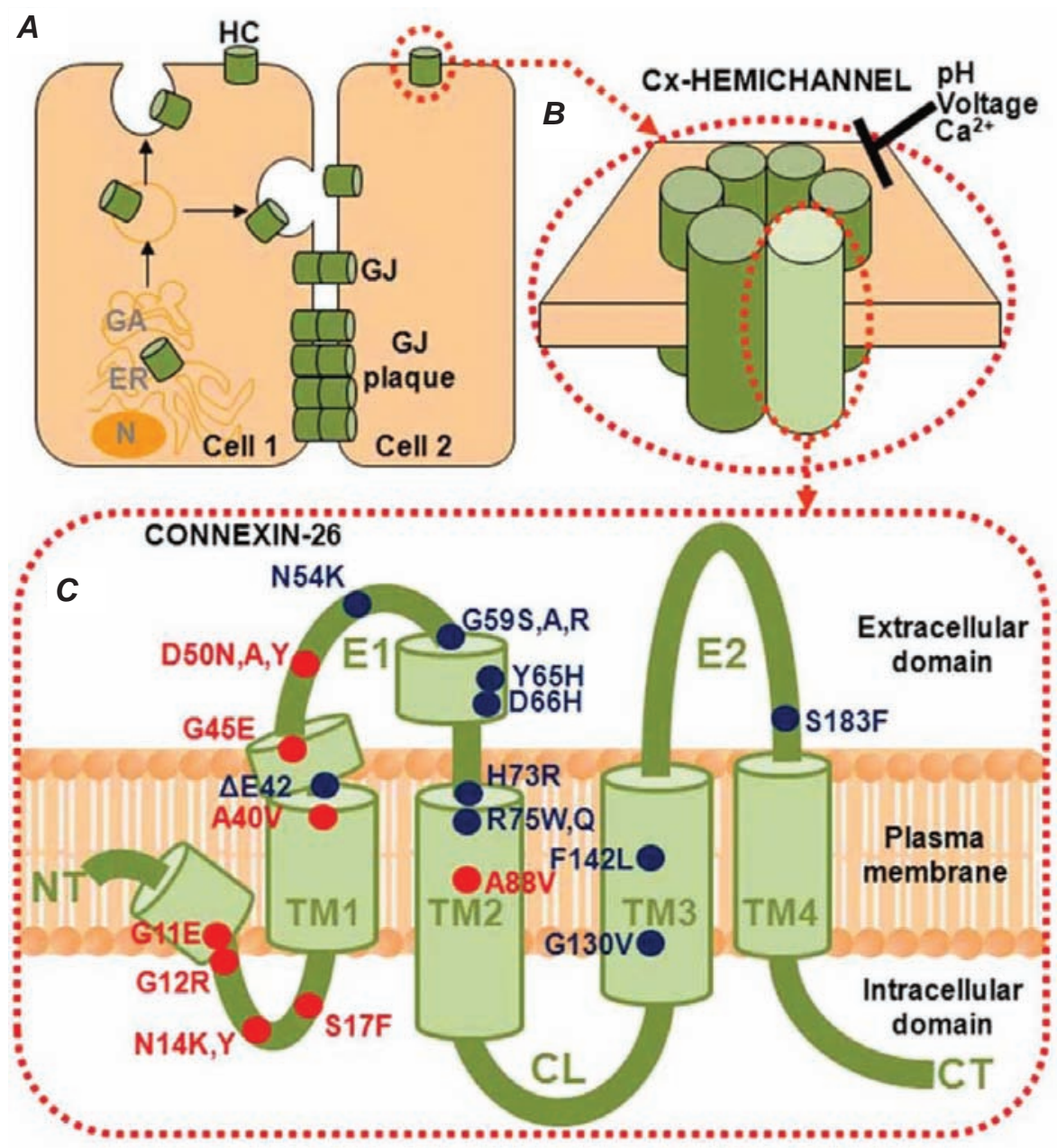

Fig. 2. This figure shows a representation of connexons in different cells forming the gap junctions. A. Location of $C \times 26$ within the membrane. B. Six of the Cx26 proteins form a hexamer and thus a gap junction channel. $C$. The structure of Cx26 showing all extracellular and intracellular domains alongside with mutations labeled on affected locations in the structure [14] 
structure [16]. This clearly shows the importance of sulfide bonds in maintaining the stability of the protein structure (Fig. 3, D).

\section{Mutations in the GJB2 gene}

As mentioned earlier, 50\% of hearing impairment cases are caused by genetic factors and most of them are due to mutations in the GJB2 gene. Because GJB2 codes for the instructions of making the protein Cx26, any changes in its nucleotide sequence might either result in a change of amino acids or deleting some of them contributing to the translation of a connexin 26 with an abnormal structure [18]. This irregular structure of the protein, whether it is incomplete or lost an essential bond that connects it with other monomers, it will surely lead it to be a faulty protein as all of its structure components plays a key role in stabilizing it, and so making able to carry its normal function [18].

According to recent research, the most common connexin 26 mutation is $35 \mathrm{delG}$, and it is a frame shift mutation that involves the deletion of Guanine base at position 35, causing in a shifting of the sequence, and thus resulting in TGA, a premature stop codon. Consequently, the coding sequence is terminated resulting in a shortened Cx26 protein [18].

Another important mutation that is worth considering is Cys169Tyr. This is a missense mutation, which also is a point mutation where one nucleotide change would lead to a codon that codes for a different amino acid [19]. Correspondingly, in the codon TGC that codes for the amino acid cysteine at position 167, in the protein sequence of 226 amino acids, the mutation involves the switch of nitroge-
$\boldsymbol{A}$

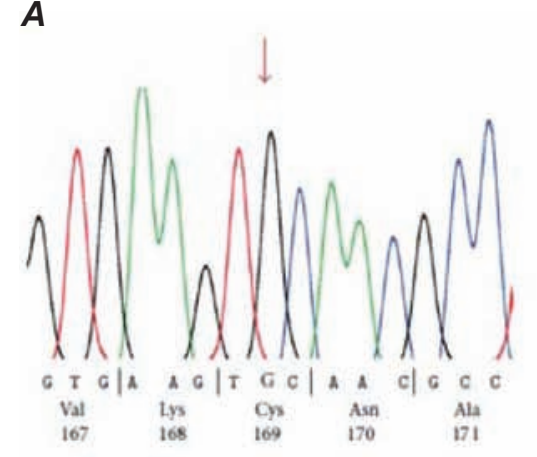

B

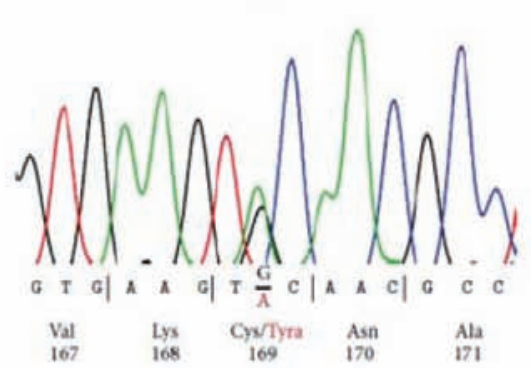

c

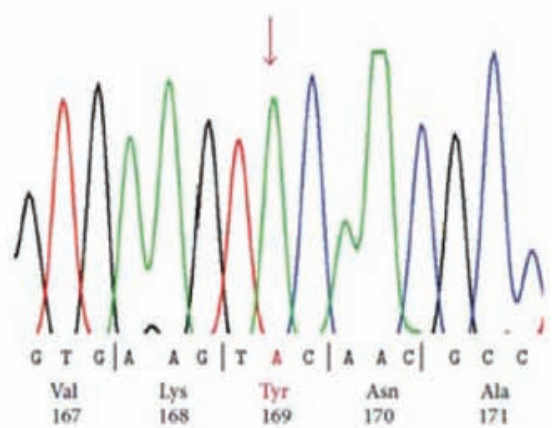

D

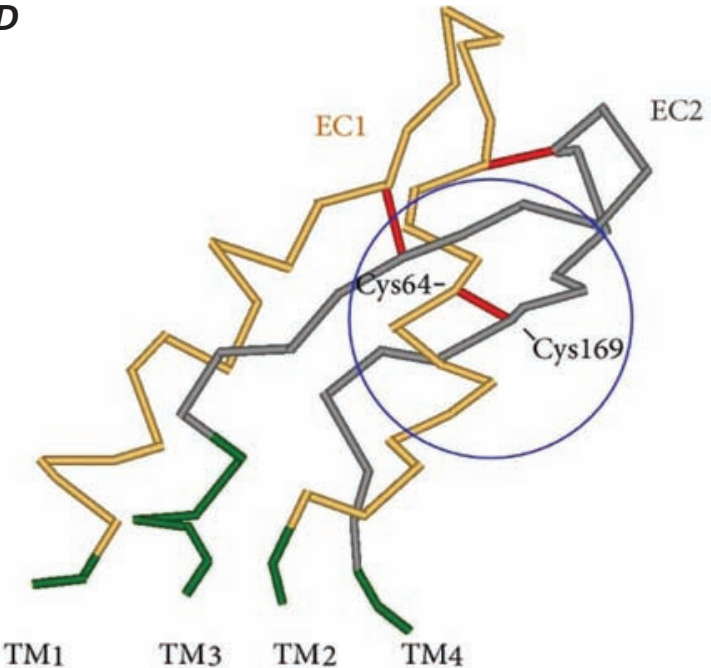

E

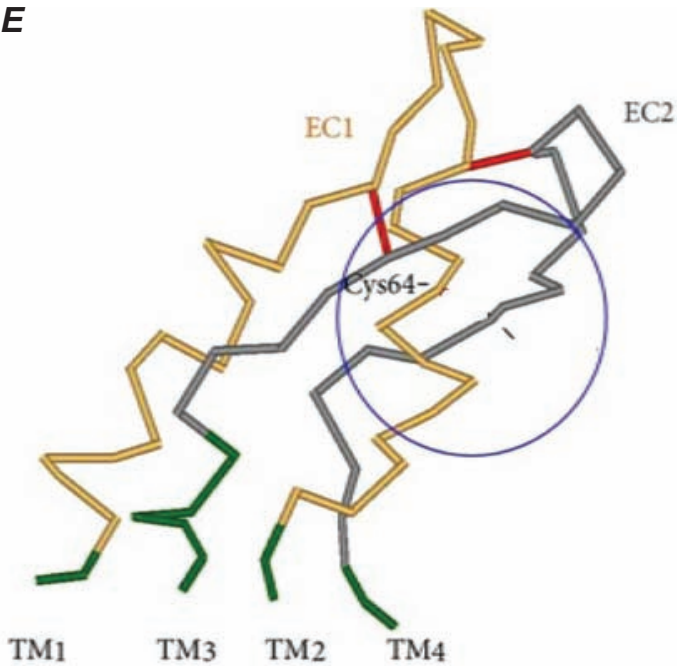

Fig. 3. Illustrates the process of Cys1697yr mutation. A. The normal sequence, $\boldsymbol{B}$. demonstrates where the base guanine was switched to adenine, and $\boldsymbol{C}$. The mutated sequence where tyrosine was coded instead of cysteine. D. Schematic representation of Cx26 normal structure. The three disulfide bonds are colored in red, and two cysteine amino acids 64 and 169 form one disulfide bond. E. Schematic representation of Cx26, where the CYS 169 residue is replaced with tyrosine. It results in the loss of a crucial disulfide bond, which contribute to the stabilization of the protein structure [17] 
nous base Guanine to Adenine, which consequently lead to the translation of tyrosine instead of cysteine as presented in Fig. 3, A-C.

Although the translation of protein structure is completed, the resulting protein has an abnormal structure of the extracellular domain E2 [17]. This mutation occurs in a highly conserved region, which affects one of the three cysteine residues responsible for disulfide bonds, which are extremely important for the connexon-connexon interaction. These as well stabilize the three-dimensional structure between the extracellular domains E1 and E2 of the protein connexin 26 [19].

Cys169Tyr results in the destruction of a third disulfide bridge between cysteine residues 64 and 169 in the protein complex as shown in Fig. 3, E [17]. This leads to the alteration of the three-dimensional structure of the whole connexin 26 molecule [19]. Consequently, the inhibition of the interactions between connexons of neighboring cells would occur as well as proper anchoring of connexions in the membrane [20]. Accordingly, the interactions between the cells are affected due to the changes occurring in the connexin protein structures [19]. Therefore, the exchange of low-molecular substances can no longer occur, as well as the regulation of the potassium ions homeostasis. This will hinder other processes in the inner ear and would eventually result in hearing loss [19, 20].

\section{Future perspectives}

In order to treat this condition, conducting further research on using interference RNA and gene therapy is highly recommended. According to scientific literature, this was successfully attempted on transgenic mice and it has resulted in promising results [21]. Using small interference RNA mechanism, the target mRNA, Cys169Tyr Gjb2 in this case is degraded in the cytoplasm after transcription and so down regulating the gene expression [22]. The viral packaging and delivery of miRNA to Gjb2 Cys169Tyr human embryos would result in long-term silencing of the Cys169Tyr genes. In addition, the best proposed vector is "bovine adeno associated virus", which is a single stranded DNA virus and has been shown to be very efficient in gene transfer, as well as relatively safe for causing no cytotoxicity according to previous work done by researchers [21]. The BAA viruses could be then injected to the human embryonic cells in the uterus through microinjections methods at suitable time (Before the cochlea develops). Finally, the expression of the genes can be assessed using western blots and the newborn hearing processes using 'Auditory brainstem responses' [21,22]. For this reason, advanced research on orphan diseases such as inherited deafness due to GJB2 mutations using gene therapy and other molecular techniques is highly encouraged.

In conclusion, the proper function of the connexin 26 protein can be achieved thanks to the proper bonding of the three disulfide bridges at the cysteine residues 53 and 180, 60 and 174, in addition to 64 and 169. These cysteine residues are crucial in maintaining the stability of the protein structure. When the missense mutation in the GJB2 gene occurs, the cysteine residue in position 169 is replaced by a tyrosine, resulting in the loss of one disulfide bridge that is binding two connexons. Since the binding happens between the domains E1 and E2 of the connexons, no gap junction would be formed, where the potassium ions can move and contribute to the hearing process. The loss of this crucial biological function will result in deafness, which is a serious health problem that is affects many individuals, and can be treated using gene therapy in near future.

\section{РОЛЬ ГЕНА GJВ2 I КОНЕКСИНУ 26 У РОЗВИТКУ ПАТОЛОГІЙ СЛУХУ}

\section{Asmaa Missoum}

Department of Biological and Environmental Sciences, Qatar University, Doha, Qatar; e-mail: amissoum@live.com

Мутації гена GJB2 (Gap Junction Beta 2) € однією $з$ головних причин спадкового порушення слуху. Цей ген кодує різні протеїни щілинних контактів, зокрема конексину 26 (Сх26), який сприяє гомеостазу $\mathrm{K}^{+}$всередині равлика внутрішнього вуха. Мутації GJB2 також виявлено у разі несиндромальної глухоти (75\% випадків), яка не супроводжується іншими аномаліями в організмі. Сх26 складається з чотирьох трансмембранних спіралей і двох позаклітинних петель, в кожній $з$ яких $є$ три специфічних, консервативних залишки цистеїну, зв'язаних внутрішньомолекулярними дисульфідними містками. Мутації 35delG i Cys169Tyr є найпоширенішими мутаціями GJB2. Перша призводить до скорочення протеїну Сх26 через переривання послідовності, що кодує, а друга - до дестабілізації структури протеїну через пошкодження 
одного із трьох залишків цистеїну. В цьому короткому огляді надано додаткові дані про те, як ці два типи мутацій призводять до втрати слуху.

Ключнов с слова: Gap Junction Beta 2 (GJB2) ген, конексин 26 (Сх26), несиндромальна форма, 35delG, Cys169Tyr, спадкова туговухість.

\section{РОЛЬ ГЕНА GJВ2 И КОННЕКСИНА 26 В РАЗВИТИИ ПАТОЛОГИЙ СЛУХА}

\section{Asmaa Missoum \\ Department of Biological and Environmental Sciences, Qatar University, Doha, Qatar; e-mail: amissoum@live.com}

Мутации гена GJB2 (Gap Junction Beta 2) являются одной из главных причин наследственного нарушения слуха. Этот ген кодирует различные протеины щелевых контактов, в частности коннексин 26 (Сх26), способствующий гомеостазу $\mathrm{K}^{+}$внутри улитки внутреннего уха. Мутации GJB2 также выявлены при несиндромальной тугоухости (в 75\% случаев), которая не сопровождается другими аномалиями в организме. Сх26 состоит из четырех трансмембранных спиралей и двух внеклеточных петель, в каждой из которых имеется три специфических, консервативных остатка цистеина, связанных внутримолекулярными дисульфидными мостиками. Мутации 35delG и Cys169Tyr являются наиболее распространенными мутациями GJB2. Первая приводит к укороченному протеину Сх26 из-за прерывания кодирующей последовательности, а вторая - к дестабилизации его структуры из-за повреждения одного из трех остатков цистеина. В этом коротком обзоре представлены дополнительные данные о том как эти два типа мутаций приводят к потере слуха.

К л ю че вы е с л о в а: Gap Junction Beta 2 (GJB2) ген, коннексин 26 (Сх26), несиндромальная форма, 35delG, Cys169Tyr, наследственная тугоухость.

\section{References}

1. Shen N, Peng J, Wang X, Zhu Y, Liu W, Liu A, $\mathrm{Lu}$ Y. Association between the p.V37I variant of GJB2 and hearing loss: a pedigree and metaanalysis. Oncotarget. 2017; 8(28): 46681-46690.

2. Meena R, Ayub M. Genetics Of Human Hereditary Hearing Impairment. J Ayub Med Coll Abbottabad. 2017; 29(4): 671-676.

3. Chan DK, Chang KW. GJB2-associated hearing loss: systematic review of worldwide prevalence, genotype, and auditory phenotype. Laryngoscope. 2014; 124(2): E34-E53.

4. Zhao HB. Hypothesis of $\mathrm{K}(+)$-Recycling Defect Is Not a Primary Deafness Mechanism for Cx26 (GJB2) Deficiency. Front Mol Neurosci. 2017; 10: 162.

5. Yan D, Xiang G, Chai X, Qing J, Shang H, Zou B, Mittal R, Shen J, Smith RJ, Fan YS, Blanton SH, Tekin M, Morton C, Xing W, Cheng J, Liu XZ. Screening of deafness-causing DNA variants that are common in patients of European ancestry using a microarray-based approach. PLoS One. 2017; 12(3): e0169219.

6. Wingard JC, Zhao HB. Cellular and Deafness Mechanisms Underlying Connexin MutationInduced Hearing Loss - A Common Hereditary Deafness. Front Cell Neurosci. 2015; 9: 202.

7. Berto A, Pellati D, Castiglione A, Busi M, Trevisi P, Gualandi F, Martini A. Audiological profiles and gjb2, gjb6 mutations: A retrospective study on genetic and clinical data from 2003 to 2008. Audiolog Med. 2009; 7(2): 93-105.

8. Kemperman MH, Hoefsloot LH, Cremers CW. Hearing loss and connexin 26. $J$ R Soc Med. 2002; 95(4): 171-177.

9. Augustine G, Purves D. Hair Cells and the Mechanoelectrical Transduction of Sound Waves. In Neuroscience (2nd Edition ed.). Sunderland (MA): Sinauer Associates, 2001.

10. Qiu X, Müller U. Mechanically Gated Ion Channels in Mammalian Hair Cells. Front Cell Neurosci. 2018; 12: 100. 
11. Fettiplace R. Hair Cell Transduction, Tuning, and Synaptic Transmission in the Mammalian Cochlea. Compr Physiol. 2017; 7(4): 1197-1227.

12. Parzefall T, Frohne A, Koenighofer M, Kirchnawy A, Streubel B, Schoefer C, Frei K, Lucas $\mathrm{T}$. Whole-exome sequencing to identify the cause of congenital sensorineural hearing loss in carriers of a heterozygous GJB2 mutation. Eur Arch Otorhinolaryngol. 2017; 274(10): 36193625.

13. Lin L, Wang YF, Wang SY, Liu SF, Yu Z, Xi L, Li HW. Ultrastructural pathological changes in the cochlear cells of connexin 26 conditional knockout mice. Mol Med Rep. 2013; 8(4): 10291036.

14. Sanchez HA, Verselis VK. Aberrant Cx26 hemichannels and keratitis-ichthyosis-deafness syndrome: insights into syndromic hearing loss. Front Cell Neurosci. 2014; 8: 354.

15. Cheung G, Chever O, Rouach N. Connexons and pannexons: newcomers in neurophysiology. Front Cell Neurosci. 2014; 8: 348.

16. Del Castillo FJ, del Castillo I. The DFNB1 subtype of autosomal recessive non-syndromic hearing impairment. Front Biosci. 2011; 16: 3252-3274.

17. Birkenhäger R, Prera N, Aschendorff A, Laszig R, Arndt S. A novel homozygous mutation in the EC1/EC2 interaction domain of the gap junction complex connexon 26 leads to profound hearing impairment. Biomed Res Int. 2014; 2014: 307976.
18. Chun JY, Shin SK, Min KT, Cho W, Kim J, Kim SO, Hong SP. Performance evaluation of the TheraTyper-GJB2 assay for detection of GJB2 gene mutations. J Mol Diagn. 2014; 16(5): 573-583.

19. Zonta F, Girotto G, Buratto D, Crispino G, Morgan A, Abdulhadi K, Alkowari M, Badii R, Gasparini P, Mammano F. The p.Cys169Tyr variant of connexin 26 is not a polymorphism. Hum Mol Genet. 2015; 24(9): 2641-2648.

20. Tlili A, Al Mutery A, Kamal Eddine Ahmad Mohamed W, Mahfood M, Hadj Kacem H. Prevalence of GJB2 Mutations in Affected Individuals from United Arab Emirates with Autosomal Recessive Nonsyndromic Hearing Loss. Genet Test Mol Biomarkers. 2017; 21(11): 686-691.

21. Sheffield, Abraham Matthias. "Gene therapy for hereditary hearing loss: lessons from a mouse model." PhD (Doctor of Philosophy) thesis, University of Iowa, 2012. https://ir.uiowa.edu/ etd/2984.

22. Crispino G, Di Pasquale G, Scimemi P, Rodriguez L, Galindo Ramirez F, De Siati RD, Santarelli RM, Arslan E, Bortolozzi M, Chiorini JA, Mammano F. BAAV mediated GJB2 gene transfer restores gap junction coupling in cochlear organotypic cultures from deaf Cx26Sox10Cre mice. PLoS One. 2011; 6(8): e23279.

Received 10.09.2018 